\title{
ANALISIS MOTIVASI DAN GAYA BELAJAR TERHADAP HASIL BELAJAR MATEMATIKA SISWA DI KELAS IV SDS AMALIA MEDAN
}

\author{
Tri Astari \\ Dosen Prodi Pendidikan Guru Sekolah Dasar
}

\begin{abstract}
This study aims to analyze the motivation and learning styles to the results of learning the mathematics of IV students SDS Amalia Medan. This type of research is a qualitative descriptive. The population and sample of this research are 23 students of class IV. Data analysis comes from observation, observation, and questionnaire. The result of motivation analysis obtained very high motivation percentage $13,04 \%$ (3 person), high 56,52\% (13 persons), low 21,74\% (5 person), and very low 8,70\% (2 person). Many students completed KKM with very high motivation as much as 2 people, high as many as 13 people, and low as much as 1 person. The result of learning style analysis was 15 students $(65,22 \%)$ with visual learning style, 5 students $(21,74 \%)$ had an auditory learning style, and 3 students $(13,04 \%)$ with kinesthetic learning style. Many students who complete the learning outcomes (beyond the limit of KKM 70) by using semester exam questions as the test is 12 visual persons (52.17\%), 3 auditory (13.04\%) and 1 kinesthetic (4.35\%). Based on the results of data analysis, the motivation and learning style influence the learning outcomes of mathematics.
\end{abstract}

Keywords: learning motivation, learning style, and learning result in mathematics.

\begin{abstract}
Abstrak: Penelitian ini bertujuan untuk menganalisis motivasi dan gaya belajar terhadap hasil belajar matematika siswa kelas IV SDS Amalia Medan. Jenis penelitian ini merupakan kualitatif deskriptif. Populasi dan sampel penelitian ini adalah 23 siswa kelas IV. Analisis data berasal dari hasil observasi, pengamatan, dan angket. Hasil analisis motivasi belajar diperoleh persentase motivasi sangat tinggi 13,04\% (3 orang), tinggi $56,52 \%$ (13 orang), rendah 21,74\% (5 orang), dan sangat rendah 8,70\% (2 orang). Banyak siswa yang tuntas KKM dengan motivasi sangat tinggi sebanyak 2 orang, tinggi sebanyak 13 orang, dan rendah sebanyak 1 orang. Hasil analisis gaya belajar terdapat 15 orang siswa $(65,22 \%)$ yang memiliki gaya belajar visual, 5 orang siswa $(21,74 \%)$ memiliki gaya belajar auditori, dan 3 orang siswa $(13,04 \%)$ dengan gaya belajar kinestetik. Banyak siswa yang tuntas hasil belajarnya (melampaui batas $\mathrm{KKM} \geq 70$ ) dengan menggunakan soal ujian semester sebagai tesnya adalah 12 orang visual $(52,17 \%), 3$ orang auditori $(13,04 \%)$ dan 1 orang kinestetik $(4,35 \%)$. Berdasarkan hasil analisis data maka motivasi dan gaya belajar mempengaruhi hasil belajar matematika.
\end{abstract}

Kata Kunci: motivasi belajar, gaya belajar, dan hasil belajar matematika.

\section{Pendahuluan}

Berdasarkan penelitian terdahulu, penulis ingin mengulang kembali penelitian sebelumnya (Astari, 2017) mengenai Analisis Gaya Belajar Terhadap Hasil Belajar Matematika di Kelas V SD Negeri 064036 Medan. Perbedaan penelitian kedua ini adalah penulis menambahkan satu variabel yaitu motivasi belajar. Dimana dalam proses belajar, motivasi sangat diperlukan sebab seseorang yang tidak mempunyai motivasi dalam belajar tidak akan mungkin melakukan aktivitas belajar. Suatu pendorong yang mengubah energi dalam diri seseorang ke dalam bentuk aktivitas nyata untuk mencapai tujuan tertentu disebut motivasi (Djamarah, 2002). Selain itu, motivasi dan gaya belajar merupakan salah satu faktor belajar yang berpengaruh besar dalam pencapaian hasil belajar.

Berdasarkan observasi yang dilakukan oleh peneliti di SDS Amalia Medan tepatnya di kelas IV terdapat permasalahan yang sama dengan penelitian sebelumnya yaitu sebagian siswa di kelas ini gaya belajarnya beraneka ragam. Namun, guru belum mampu memahami sehingga menyampaikan materi pelajaran lebih banyak dengan mencatat dan 
berceramah. Guru belum menyadari matematika merupakan pelajaran yang membutuhkan bentuk konkrit bukan abstrak sehingga peserta didik mendengarkan materi pelajaran dengan melalui catatan di papan tulis dan ceramah yang dilakukan oleh guru. Guru jarang mengaitkan pembelajaran matematika dengan kehidupan sehari-hari siswa, sehingga peerta didik kesulitan dalam memahami konsep matematika.

Dalam pembelajaran, peserta didik terlihat kurang berminat terhadap matematika. Hal ini ditunjukan oleh sikap mereka saat mereka menerima pembelajaran, siswa di kelas cenderung pasif (saat pelajaran berlangsung) seolah-olah belum siap menerima pelajaran, siswa tidak mau bertanya selama dalam proses pembelajaran, siswa belajar dengan cara yang monoton.

Berdasarkan keadaan tersebut akan dilakukan penelitian yang berkaitan dengan analisis motivasi dan gaya belajar anak terhadap hasil belajarnya. Dimana mata pelajaran yang menjadi tolak ukurnya adalah pelajaran matematika. Besarnya peranan mata pelajaran matematika dengan kehidupan sehari-hari mengharuskan mata pelajaran matematika wajib diajarkan dan dikuasai siswa di jenjang pendidikan dasar hingga perguruan tinggi. Dengan menganalisis gaya belajar peserta didik terhadap hasil belajar matematika diharapkan memperoleh gambaran motivasi dan gaya belajar peserta didik sehingga guru mampu memfasilitasi strategi belajar yang sesuai agar peserta didik termotivasi dalam pembelajaran matematika dan memperoleh hasil belajar yang optimal.
9 Pages pp. 1-9

\section{Kajian Pustaka}

\section{Motivasi Belajar}

Kata motif, diartikan sebagai upaya yang mendorong seseorang untuk melakukan sesuatu. Motivasi dapat juga dikatakan serangkaian usaha untuk menyediakan kondisikondisi tertentu, sehingga seseorang mau dan ingin melakukan sesuatu, dan bila ia tidak suka, maka akan berusaha untuk meniadakan atau mengelakkan perasaan tidak suka itu. Jadi motivasi itu dapat dirangsang oleh faktor dari luar tetapi motivasi itu perlu tumbuh di dalam diri seseorang. Keseluruhan daya penggerak di dalam diri siswa yang menimbulkan kegiatan belajar, yang menjamin kelangsungan dari kegiatan belajar dan memberikan arah pada kegiatan belajar, sehingga tujuan yang dikehendaki oleh objek belajar itu tercapai disebut motivasi belajar (Sardiman, 2011).

\section{Gaya Belajar}

Gaya belajar mengacu pada cara belajar yang lebih disukai pembelajar. Umumnya, dianggap bahwa gaya belajar seseorang berasal dari variabel kepribadian, termasuk susunan kognitif dan psikologis latar belakang sosio cultural, dan pengalaman pendidikan (Nunan, 1991).

Keanekaragaman gaya belajar siswa perlu diketahui pada awal permulaannya diterima pada suatu lembaga pendidikan yang akan ia jalani. Hal ini akan memudahkan bagi pembelajar untuk belajar maupun pembelajar untuk mengajar dalam proses pembelajaran. Pembelajar akan dapat belajar dengan baik dan hasil belajarnya baik, apabila ia mengerti gaya belajarnya. Hal tersebut memudahkan 
pembelajar dapat menerapkan pembelajaran dengan mudah dan tepat (Kolb, 1984).

Tiap individu memiliki kekhasan sejak lahir dan diperkaya melalui pengalaman hidup. Yang pasti semua orang belajar melalui alat inderawi, baik penglihatan, pendengaran, dan kinestetik. Setiap orang memiliki kekuatan belajar atau gaya belajar. Semakin kita mengenal baik gaya belajar kita maka akan semakin mudah dan lebih percaya diri di dalam menguasai suatu keterampilan dan konsepkonsep dalam hidup.

Berikut ini adalah definisi gaya belajar (Nasution, 2006), yaitu: (1) learning style, "refers to a student's consistent way of responding to and using stimuli in the context of learning. (2) cognitive style: characteristic cognitive modes of functioning that we reveal throughout our perceptual and intellectual activities in highly consistent and pervasive way (Witkin), (3) cognitive style is a "superordinate construct which is involved in many cognitive operations, and which accounts for individual differences in a variety of cognitive, perceptual, and personality variable"(Vernon), and (4) cognitive style represents a person's typical modes of perceiving, remembering, thinking and problem-solving (Messick).

Menurut Deporter dan Hernacki dalam Purnawati (2014: 63), gaya belajar merupakan kombinasi menyerap, mengatur, dan mengolah informasi. Mudahnya begini, anda memiliki lima indra, yaitu melihat, mendengarkan, meraba, mencium, dan merasakan. Dari lima indra tersebut, hanya tiga yang dipakai belajar, yaitu melihat (visual), mendengarkan (auditory), dan merasakan (touch).

Sebenarnya, gaya belajar anak muncul dipengaruhi oleh faktor bawaan atau sudah dari sananya. Ada anak yang memang memiliki fisik kuat dan prima sehingga cenderung pp. 1-9

9 Pages

memiliki gaya belajar kinestetik. Atau ada juga anak yang memiliki rasa seni tinggi sehingga gaya belajar visual lebih melekat dalam dirinya.

Jika salah satu indera kurang berfungsi secara maksimal, maka umumnya indera lain akan menggantikannya. Jika penglihatan seorang anak kurang berfungsi, maka indra pendengarannya lebih menonjol sehingga ia lebih peka terhadap suara atau bunyi-bunyian. Contohnya, para penyandang tunanetra biasanya memiliki indra pendengaran yang sangat tajam.

Selain itu, pola asuh juga memegang peran penting dalam kemunculan gaya belajar seseorang. Maksudnya, gaya belajar ditentukan oleh sejauh mana orang tua melakukan stimulasi terhadap masing-masing indra anaknya. Anak yang sejak kecil terbiasa dibacakan dongeng, boleh jadi akan terbiasa untuk mengasah kemampuan pendengarannya. Ia juga bisa cepat mencerna ucapan sang pendongeng. Akibatnya, anak akan cenderung menjadi seorang auditory learner dalam gaya belajarnya. Sementara anak seorang pelukis yang mayoritas waktunya lebih tercurah untuk mengamati detail-detail gambar orang tuanya biasanya akan menjadi seseorang dengan tipe belajar visual.

Jadi jika media belajar anak paling baik melalui membaca dan melihat gambar, mereka disebut " visual learning style". Jika media belajarnya paling baik melalui pendengarannya, mereka disebut "auditory learning style", sedangkan jika media belajarnya adalah latihan untuk mendapatkan hasil yang terbaik, mereka disebut "touching 
Jurnal Ilmu Pendidikan Guru dan Sosial STKIP Citra Bangsa Aceh Utara

9 Pages

ISSN 2615-5036 pp. 1-9

learning style". Dengan mengetahui ini, guru dapat membantu anak belajar dengan lebih efektif.

Dari beberapa definisi belajar di atas dapat disimpulkan bahwa gaya belajar adalah cara yang dipakai seseorang dalam proses belajar meliputi bagaimana menangkap, mengatur serta mengolah informasi yang diterima sehingga pembelajaran menjadi efektif.

Ada beberapa tipe gaya belajar yang harus dicermati oleh guru yaitu: gaya belajar visual (visual learner), gaya belajar auditif (auditory learner), dan gaya belajar kinestetik (tactual learner). Gaya belajar tersebut memiliki penekanan-penekanan masingmasing, meskipun perpaduan dari ketiganya sangatlah baik, tetapi pada saat tertentu siswa akan menggunakan salah satu dari ketiga gaya belajar tersebut. Tipe Belajar Visual (Visual Learner)

Visual learner adalah gaya belajar di mana gagasan, konsep data dan informasi lainnya dikemas dalam gambar dan teknik. Siswa yang memiliki gaya belajar visual memiliki ketertarikan yang tinggi ketika diperlihatkan gambar, grafik, grafis organisatoris, seperti jaring, peta konsep dan ide peta, plot dan ilustrasi visual lainnya. Beberapa teknik yang digunakan dalam belajar visual untuk meningkatkan keterampilan berpikir dan belajar, lebih mengedepankan peran penting mata penglihatan (visual).

Ciri-ciri dan kelemahan gaya belajar visual adalah sebagai berikut:

- Kesulitan memahami pesan yang disampaikan secara lisan.
- Memiliki kecenderungan memperhatikan sikap dan gerakan bibir guru yang sedang mengajar atau seseorang yang sedang menerangkan.

- Masuk kategori pendengar yang kurang baik saat berkomunikasi.

- Cenderung pasif bila dalam kegiatan kelompok atau diskusi.

- Membutuhkan alat peraga saat penjelasan dilakukan.

- Tidak merasa terganggu dengan segala suara yang hingar-bingar.

\section{Tipe Belajar Auditif (Auditory Learner)}

Auditory learner adalah suatu gaya belajar di mana siswa belajar melalui mendengarkan, menggunakan indera pendengar untuk menginterprestasikan maksud informasi yang didapatkan dengan memerhatikan intonasi, nada suara, kecepatan berbicara, dan nuansa hati pembicara. Siswa yang memiliki gaya belajar auditori akan mengandalkan kesuksesan dalam belajarnya melalui telinga (alat pendengarannya), oleh karena itu, guru sebaiknya memperhatikan siswanya hingga ke alat pendengarannya. Anak yang mempunyai gaya belajar auditori dapat belajar lebih cepat dengan menggunakan diskusi verbal dan mendengarkan penjelasan apa yang dikatakan guru. Mereka menyenangi belajar melalui ceramah, kuliah lisan, diskusi, berbicara berbagai hal melalui tanya jawab, dan mendengarkan orang tentang suatu hal. Anak dengan belajar tipe ini dapat mencerna makna yang disampaikan oleh guru melalui verbal simbol atau suara, tinggi rendahnya, kecepatan berbicara dan hal-hal auditori lainnya. Anak-anak seperti ini dapat menghafal 
lebih cepat melalui membaca teks dengan keras atau mendengarkan media audio.

Ciri-ciri dan kelemahan gaya belajar auditori adalah sebagai berikut:

- Anak mampu menjadi pendengar ulung dan mudah menguasai materi/ topik melalui suara.

- Senang berdebat, berdiskusi, berkomunikasi.

- Kurang memperhatikan pengumuman atau informasi yang ditulis di mading (majalah dinding) misalnya.

- Cenderung untuk berbicara dalam porsi besar.

\section{Tipe Belajar Kinestetik (Tactual Learner)}

Tactual learner siswa belajar dengan cara melakukan, menyentuh, merasa, bergerak, dan mengalami. Anak yang mempunyai gaya belajar kinestetik mengandalkan belajar melalui bergerak, menyentuh dan melakukan tindakan. Misal, bila dalam pelajaran anatomi, maka dibutuhkan boneka untuk disentuhnya agar mudah mengingat. Anak seperti ini sulit untuk duduk diam berjam-jam karena keinginan mereka untuk beraktivitas dan eksplorasi sangatlah kuat. Siswa yang bergaya belajar seperti ini belajarnya melalui gerak dan sentuhan. Oleh karena itu pembelajaran yang dibutuhkan adalah pembelajaran yang lebih bersifat kontekstual dan praktik.

Ciri-ciri dan kelemahan gaya belajar kinestetik adalah sebagai berikut:

- Menyentuh segala sesuatu yang dilihatnya, termasuk saat belajar.

- Selalu bergerak, menyukai permainan/ aktivitas fisik. pp. 1-9

- Selalu melakukan aktivitas yang mungkin dilihat oleh guru aktivitas itu mengganggu seperti menggambar saat guru menerangkan.

- Mengalami kesulitan belajar saat belajar peta buta, simbol dan lambang.

- Menyukai kegiatan di laboratorium, misal dengan melakukan percobaan lab.

- Cenderung terburu-buru dalam mengerjakan sesuatu proyek.

\section{Hasil Belajar Matematika}

Hasil belajar terdiri dari dua kata yaitu "hasil" dan "belajar". Hasil merupakan akibat dari yang ditimbulkan karena berlangsungnya suatu proses kegiatan. Sedangkan belajar adalah serangkaian kegiatan untuk memperoleh perubahan tingkah laku sebagai hasil pengalaman individu dalam interaksi dengan lingkungannya.

Proses belajar mengajar dikelas mempunyai tujuan yang bersifat transaksional, artinya diketahui secara jelas dan operasional oleh guru dan siswa. Tujuan tercapai jika siswa memperoleh hasil belajar seperti yang diharapkan didalam proses belajar mengajar tersebut. Oleh sebab itu, hasil belajar harus dirumuskan dengan baik untuk dapat dievaluasi pada akhir pembelajaran.

Hasil belajar pada hakikatnya adalah perubahan tingkah laku individu yang relatif menetap sebagai hasil interaksi dengan lingkungan. Hasil belajar matematika tentu saja harus dikaitkan dengan tujuan pendidikan matematika yang telah dicantumkan dalam garis-garis besar program pengajaran matematika di sekolah dengan tidak melupakan hakikat matematika itu sendiri. 
Hasil belajar yang dicapai dapat diketahui bila diadakan pengukuran dari pengetahuan siswa itu. Untuk mengukur samapai dimana tingkat pengetahuan siswa harus ada alat pengukuran tertentu yang difungsinya adalah mengukur hasil belajar. Hasil adalah akibat, kesudahan dari suatu ujian dan sebagainya (Tim Penyusun KBBI, 2002).

Hasil belajar matematika adalah akibat dari suatu aktivitas yang dapat diketahui perubahannya dalam pengetahuanpengetahuan, keterampilan dan nilai sikap setelah melalui ujian dalam bidang ilmu matematika. Matematika adalah pengetahuan yang berkaitan dengan struktur abstrak dan hubungan antar-struktur tersebut terorganisasi dengan baik. Sementara Kline pada 1972 (dalam Runtukahu, 2013), Matematika adalah pengetahuan yang tidak berdiri sendiri, tetapi dapat membantu manusia untuk memahami dan memecahkan permasalahan sosial, ekonomi dan lain-lain. Dewasa ini kegiatan Matematika lebih diutamakan pada pembelajaran pendidikan dasar yang disesuaikan dengan gaya belajar, kebutuhan anak didik dan dunia nyata. Sehingga hasil belajar Matematika dapat dilihat dari kemampuan peserta didik dalam menerima pada proses pembelajaran dengan kemampuan dan gaya belajar masing-masing setelah mengalami tes.

\section{METODE PENELITIAN}

Penelitian ini adalah penelitian kualitatif deskriptif yang ditunjang oleh data yang diperoleh melalui observasi, pengamatan, dan angket. Populasi dan sampel penelitian ini adalah 23 siswa kelas IV SDS Amalia Medan.

\section{HASIL PEMBAHASAN}

Hasil perhitungan data motivasi belajar secara lengkap disajikan pada Tabel 1.

Tabel 1 Hasil Angket Motivasi Belajar Siswa

\begin{tabular}{|c|c|c|c|c|}
\hline Interval & Kriteria & Frekuensi & $\begin{array}{c}\text { Persentase } \\
(\%)\end{array}$ & $\begin{array}{c}\text { Banyak Siswa } \\
\text { yang Tuntas } \\
\text { KKM (orang) }\end{array}$ \\
\hline $85-100$ & $\begin{array}{c}\text { Sangat } \\
\text { Tinggi }\end{array}$ & 3 & 13,04 & 2 \\
\hline $69-84$ & Tinggi & 13 & 56,52 & 13 \\
\hline $53-68$ & Rendah & 5 & 21,74 & 1 \\
\hline $36-52$ & $\begin{array}{c}\text { Sangat } \\
\text { Rendah }\end{array}$ & 2 & 8,70 & - \\
\hline \multicolumn{2}{|c|}{ Jumlah } & 23 & 100 & 16 \\
\hline
\end{tabular}

Berdasarkan pada Tabel 1. di atas diketahui peserta didik yang memiliki persentase motivasi sangat tinggi $13,04 \%$ (3 orang), tinggi $56,52 \%$ (13 orang), rendah $21,74 \%$ (5 orang), dan sangat rendah $8,70 \%$ (2 orang). Banyak peserta didik yang tuntas hasil belajarnya dengan motivasi yang sangat tinggi, tinggi, rendah, dan sangat rendah dapat disajikan dalam diagram berikut:

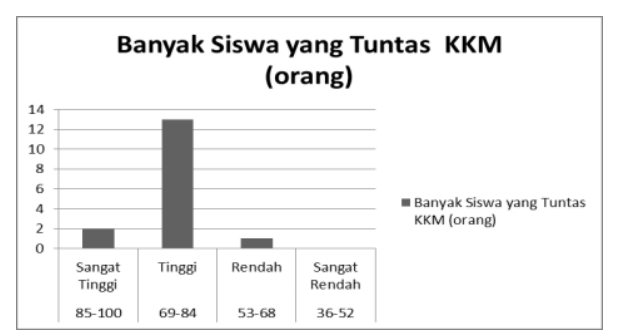

\section{Gambar 1 Diagram Gaya Belajar Kelas IV SDS Amalia Medan}

Dari diagram di atas menunjukkan bahwa motivasi mempengaruhi hasil belajar peserta didik. Dimana motivasi belajar penting diketahui bagi siswa dan guru. Bagi siswa pentingnya motivasi belajar sebagai berikut: 1) menyadarkan kedudukan pada awal belajar, 
proses, dan hasil akhir; 2) menginformasikan tentang kekuatan usaha belajar; 3) mengarahkan kegiatan belajar; 4) membesarkan semangat belajar; dan 5) menyadarkan adanya perjalanan belajar dan kemudian bekerja. Pengetahuan dan pemahaman tentang motivasi belajar pada peserta didik bermanfaat pada guru yaitu: 1) membangkitkan, meningkatkan, dan memelihara semangat siswa untuk belajar sampai berhasil; 2) mengetahui dan memahami motivasi belajar siswa di kelas bermacam ragam; 3) meningkatkan dan menyadarkan guru untuk memilih satu di antara bermacammacam peran guru; dan 4) memberi peluang guru untuk unjuk kerja rekayasa pedagogik (Dimyati dan Mudjiono; 2009).

Hasil penelitian diperoleh dari hasil pengamatan dan angket gaya belajar kelas IV SDS Amalia Medan adalah sebagai berikut:

Tabel 2 Hasil Observasi Siswa

\begin{tabular}{|c|l|c|c|}
\hline No. & $\begin{array}{c}\text { Gaya } \\
\text { Belajar }\end{array}$ & $\begin{array}{c}\text { Banyak Siswa } \\
\text { (orang) }\end{array}$ & $\begin{array}{c}\text { Persen } \\
(\%)\end{array}$ \\
\hline 1. & Visual & 15 & 65,22 \\
\hline 2. & Auditori & 5 & 21,74 \\
\hline 3. & Kinestetik & 3 & 13,04 \\
\hline \multicolumn{2}{|c|}{ Jumlah } & 23 & 100 \\
\hline
\end{tabular}

Banyak peserta didik dengan menggunakan gaya belajarnya masing-masing dapat disajikan dalam diagram sebagai berikut:
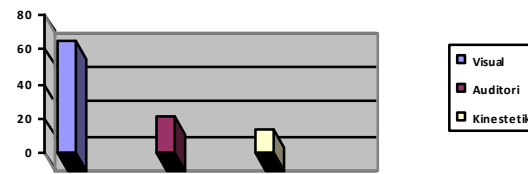

$\square$ Kinestetik

\section{Gambar 2 Diagram Gaya Belajar Kelas IV SDS Amalia Medan}

Dari diagram di atas terlihat gaya belajar visual mendominasi sebesar 65,22\%
(15 orang), auditori $21,74 \%$ (5 orang), dan kinestetik 13,04\% (3 orang). Hal tersebut juga terjadi pada penelitian terdahulu diperoleh dari hasil pengamatan, observasi, dan angket adalah terdapat 22 orang siswa $(68,75 \%)$ yang memiliki gaya belajar visual, 6 orang siswa $(18,75 \%)$ memiliki gaya belajar auditori, dan 4 orang siswa $(12,5 \%)$ dengan gaya belajar kinestetik. Hal itu dikarenakan hampir semua anak menemukan kenyamanan belajar dengan cara melihat. Mereka lebih tertarik ketika diperlihatkan gambar, grafik, grafis organisatoris, seperti jaring, peta konsep dan ide peta, plot dan ilustrasi visual lainnya.

Banyak peserta didik yang tuntas hasil belajarnya yang melewati batas KKM dapat dilihat sebagai berikut:

Tabel 3 Hasil Belajar Siswa

\begin{tabular}{|c|l|c|c|}
\hline No. & $\begin{array}{c}\text { Gaya } \\
\text { Belajar }\end{array}$ & $\begin{array}{c}\text { Banyak Siswa } \\
\text { yang Tuntas } \\
\text { KKM (orang) }\end{array}$ & $\begin{array}{c}\text { Persentase } \\
(\%)\end{array}$ \\
\hline 1. & Visual & 12 & 52,17 \\
\hline 2. & Auditori & 3 & 13,04 \\
\hline 3. & Kinestetik & 1 & 4,35 \\
\hline
\end{tabular}

Banyak peserta didik yang tuntas hasil belajarnya dengan menggunakan soal Ujian Semester Genap sebagai tesnya, disajikan dalam diagram sebagai berikut:

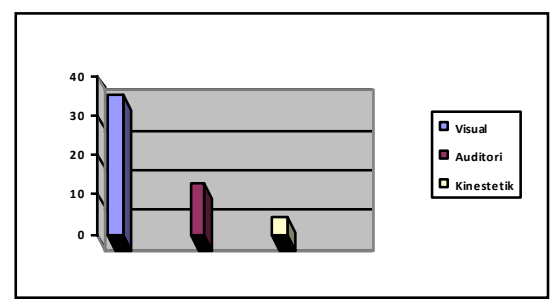

\section{Gambar 3 Diagram Hasil Belajar Kelas IV SDS Amalia Medan}


Dari diagram di atas terlihat anak-anak dengan gaya belajar visual memiliki hasil tes belajar yang lebih baik dari pada anak dengan gaya belajar yang lain. Banyak anak yang tuntas hasil belajarnya untuk visual 12 orang $(52,17 \%)$, auditori 3 orang $(13,04 \%)$, dan kinestetik 1 orang $(4,35 \%)$. Hal yang sama terjadi pada penelitian terdahulu dimana banyak siswa yang tuntas hasil belajarnya (melampaui batas $\mathrm{KKM} \geq 68,5$ ) dengan menggunakan soal tes hasil belajar pada Pokok Bahasan Pecahan sebagai tesnya adalah 6 orang visual $(18,75 \%), 2$ orang auditori $(6,25 \%)$ dan 2 orang kinestetik $(6,25 \%)$. Berdasarkan hasil analisis data maka gaya belajar mempengaruhi hasil belajar matematika. Hal ini bisa disebabkan metode yang diberikan guru mendominasi visual, yaitu membaca, menulis dan melihat papan tulis.

Gaya belajar yang dipilih peserta didik pada dasarnya memiliki tujuan yang sama, yaitu agar yang bersangkutan bisa menangkap materi pelajaran dengan sebaik-baiknya dan memberikan hasil yang optimal. Bukankah masing-masing pelajaran juga disampaikan oleh guru yang berbeda dengan karakter mengajar yang berbeda pula. Itulah mengapa, guru perlu turun tangan mengamati gaya belajar masing-masing peserta didik. Dengan memahami hal itu, sebenarnya guru sudah memberi kontribusi besar dalam keberhasilan belajar anak didiknya karena peserta didik menjadi mudah menangkap materi pelajaran khususnya pelajaran matematika.
Dalam rangka mendalami penerapan ketiga gaya belajar tersebut maka guru perlu memahami hal berikut ini:

Tabel 4 Penerapan Gaya Belajar

\begin{tabular}{|l|l|l|}
\hline $\begin{array}{c}\text { Learning } \\
\text { Style }\end{array}$ & Karakteristik & $\begin{array}{l}\text { Penerapan } \\
\text { Dalam Mengajar }\end{array}$ \\
\hline Visual & $\begin{array}{l}\text { Melihat, } \\
\text { membaca }\end{array}$ & $\begin{array}{l}\text { Mengajar dengan } \\
\text { diagram, grafik, } \\
\text { gambar, animasi, } \\
\text { transparansi, } \\
\text { video, atau alat } \\
\text { penyajian } \\
\text { informasi. }\end{array}$ \\
\hline Auditory & $\begin{array}{l}\text { Mendengar, } \\
\text { berbicara }\end{array}$ & $\begin{array}{l}\text { Tanya jawab, } \\
\text { mengajar dengan } \\
\text { memerhatikan } \\
\text { intonasi, nada } \\
\text { suara, kecepatan } \\
\text { berbicara, dan } \\
\text { nuansa } \\
\text { pembicara. hati }\end{array}$ \\
\hline Kinestetik & $\begin{array}{l}\text { Bergerak, } \\
\text { mengerjakan }\end{array}$ & $\begin{array}{l}\text { Pendekatan } \\
\text { dengan gerak } \\
\text { langsung, yang } \\
\text { bersentuhan, } \\
\text { dengan dunia fisik } \\
\text { di sekitar mereka. }\end{array}$ \\
\hline
\end{tabular}

\section{KESIMPULAN DAN SARAN}

\section{Kesimpulan}

Penelitian ini menunjukkan bahwa siswa di kelas IV SDS Amalia Medan memiliki persentase motivasi sangat tinggi $13,04 \%$ (3 orang), tinggi 56,52\% (13 orang), rendah $21,74 \%$ (5 orang), dan sangat rendah $8,70 \%$ (2 orang). Banyak siswa yang tuntas KKM dengan motivasi sangat tinggi sebanyak 2 orang, tinggi sebanyak 13 orang, dan rendah sebanyak 1 orang.

Hasil analisis gaya belajar siswa di kelas IV SDS Amalia Medan berbeda-beda yaitu visual, auditori, dan kinestetik. Hasil penelitian yang diperoleh adalah gaya belajar visual mendominasi sebesar $65,22 \% \quad(15$ orang), auditori $21,74 \%$ (5 orang), dan kinestetik 13,04\% (3 orang). Banyak siswa 
Jurnal Ilmu Pendidikan Guru dan Sosial STKIP Citra Bangsa Aceh Utara

yang tuntas hasil belajarnya (melampaui batas

$\mathrm{KKM} \geq 70)$ adalah 12 orang visual $(52,17 \%), 3$ orang auditori $(13,04 \%)$ dan 1 orang kinestetik $(4,35 \%)$. Berdasarkan hasil analisis data maka motivasi dan gaya belajar mempengaruhi hasil belajar matematika.

Saran

Guru/wali kelas sebaiknya harus memperhatikan motivasi dan gaya belajar masing-masing peserta didik. Setelah mengetahui guru diharapkan dapat memberikan strategi dan media yang tepat dalam proses pembelajaran matematika sehingga pembelajaran tidak monoton dan didominasi ceramah serta sesuai dengan gaya belajarnya.

Penelitian selanjutnya juga dapat mengembangkan penelitian ini dengan menambahkan variabel lain seperti selfefficacy, mathematics anxiety, sehingga hasil penelitian ada outcome dan representatif.

\section{DAFTAR PUSTAKA}

Astari, Tri. (2017). Analisis Gaya Belajar Terhadap Hasil Belajar Matematika Di Kelas V $S D$. Jurnal Pendidikan dan Kependidikan: REKOGNISI, Volume 2 No.2 Desember 2017. Medan: UNUSU.

B. R. Hergenhahn \& Matthew H. Olson. (2008). Theories Of Learning (Teori Belajar) Edisi Ketujuh. Jakarta: Kencana Prenada Media Group.

Dimyati dan Mudjiono. (2009). Belajar dan Pembelajaran. Jakarta: Rineka Cipta.

Djamarah dan Zain, A. (2002). Strategi Belajar Mengajar. Jakarta. Rineka Cipta.

Jihad, M. Pd., Drs. Asep dan Dr. Abdul Haris, M. Sc. (2013). Evaluasi Pembelajaran. Yogyakarta: Multi Presindo.
L. Silberman, Dr. Melvin. (2014). Active Learning 101 Cara Belajar Siswa Aktif. Bandung: Nuansa Cendekia.

Lwin, May, Khoo-Lyen-Sim. (2008). Cara Mengembangkan Berbagai Komponen Kecerdasan. Jakarta: Indeks.

Prastowo, Andi. (2013). Pengembangan Bahan Ajar Tematik. Yogyakarta: DIVA Press.

Purnamawati, Nila \& Widianto Setiono. (2014). Temukan Bakat Anak Anda. Jakarta: Panda Media.

Runtukahu, M. Ed, Ph. D,. J. Tombokan \& Drs. Selpius Kandou, M. Ap. (2013). Pembelajaran Matematika Dasar Bagi Anak Berkesulitan Belajar. Yogyakarta: Ar-Ruzz Media.

Rusman. (2013). Belajar dan Pembelajaran Berbasis Komputer. Bandung: Alfabeta.

Russel, Lou. (2011). The Accelerated Learning Fieldbook. Bandung: Nusa Media.

Sanjaya, Wina. (2008). Kurikulum dan Pembelajaran. Jakarta: Kencana Prenada Media Group.

Sardiman. (2011). Interaksi \& Motivasi Belajar Mengajar. Jakarta: Rajawali Press.

Sari, Cut Kumala Amanda. (2014). Upaya Meningkatkan Aktivitas dan Hasil Belajar Siswa Pada Mata Pelajaran Matematika Dengan Pendekatan Kontekstual (CTL) Di Kelas V SD negeri 064028 Tahun Ajaran 2013/2014. Tesis Magister Pendidikan Dasar. Medan: PPs Universitas Negeri Medan

Trianto, M. Pd. (2009). Mendesain Model pembelajaran Inovatif Progresif. Jakarta: Kencana Prenada Group.

Tung, M. Sc. Ed, M. Pd., Dr. Ir. Drs. Khoe Yao. (2015). Pembelajaran dan Perkembangan Belajar. Jakarta: PT Indeks.

Winkel. (2014). Psikologi Pengajaran. Yogyakarta: Sketsa. 